\title{
Aspidistra guangxiensis (Convallariaceae), a New Species from China
}

\author{
Saichun Tang \\ South China Institute of Botany, Chinese Academy of Sciences, Wushan, Guangzhou, \\ Guangdong 510650, People's Republic of China. tangs0448@sina.com
}

\section{Yan Liu}

Guangxi Institute of Botany, Guangxi Zhuangzu Autonomous Region, Chinese Academy of Sciences, Yanshan, Guilin, Guangxi 541006, People's Republic of China

ABstract. In the course of our investigation of the genus Aspidistra (Convallariaceae), a new species was discovered in the Guangxi Zhuangzu Autonomous Region of southern China. It is described below as A. guangxiensis S. C. Tang \& Y. Liu, and an illustration is provided.

Key words: Aspidistra, China, Convallariaceae, Guangxi.

Aspidistra Ker Gawler (Convallariaceae) consists of approximately 60 species of perennial, rhizomatous, evergreen herbs distributed in eastern Asia (China, India, Japan, Laos, Thailand, and Vietnam). Its center of distribution and differentiation is in southern China, where 56 native species (54 endemic) are known, most of them in the Guangxi Zhuangzu Autonomous Region (Lang et al., 1999; Liang \& Tamura, 2000; Fang \& Yu, 2002; He, 2002; Li \& Tang, 2002). The plants grow in seasonal rain forests (monsoon forests) and evergreen broad-leaved forests. In the course of our investigation of the genus, a new species was recently discovered in Long'an County, about 75 km northwest of Nanning in southwestern Guangxi.

Aspidistra guangxiensis S. C. Tang \& Y. Liu, sp. nov. TYPE: China. Guangxi: Guilin Botanical Garden, cultivated, 12 May 2002, Y. Liu 0001, originally collected from Guangxi, Long'an County, limestone mountains, $350 \mathrm{~m}$, date and collector not recorded (holotype, IBK; isotype, IBK). Figure 1.

Aspidistrae patentilobae affinis, sed staminibus in parte tertia infera tubi affixis, stigmate conspicue inferioro, antheris reniformibus; stigmate facie supremo alutaceo, centro 3-carinatis conspicue purpureo, infero purpureo differt.

Herbs perennial, evergreen, rhizomatous. Rhizome creeping, subterete, 3-5 mm diam., densely covered with scales. Leaves solitary, spaced; petiole
14-40 cm, partly enveloped by sheaths; leaf blade ovate to elliptic, $6-20 \times 7-8 \mathrm{~cm}$, base decurrent into petiole, apex acuminate. Flowers solitary; peduncle decumbent, 4-5 cm; bracts purple, triangular, terminal 2 or 3 close to flower; perianth abaxially purple, adaxially yellow, urceolate, fleshy; tube subglobose, $1-2 \mathrm{~cm}$ diam.; lobes 6 or 8 , free, spreading, linear-lanceolate, $2-3 \mathrm{~cm} \times 2-6 \mathrm{~mm}$, base with an adaxial, rounded, toothlike appendage extending part of the way across the mouth of the perianth tube, apex subobtuse. Stamens 6 or 8, inserted in proximal $1 / 3$ of perianth tube, positioned conspicuously lower than stigma; filament inconspicuous; anther reniform, 2-5 mm, dehiscing by a slit. Pistil ca. $1 \mathrm{~cm}$; ovary much narrower than stigma, 3-loculed; stigma sessile, dilated and bowllike, 1-1.5 cm diam., thickened, abaxially with 12 or 16 longitudinal ridges, adaxially pale yellow and slightly concave, with 3 purple ridges at center (4 ridges not observed in 4-merous flowers), margin with 12 or 16 triangular lobes.

Phenology. Flowering in May.

Distribution. Known in the wild only from limestone mountains at $350 \mathrm{~m}$ elevation in Long'an County, Guangxi Zhuangzu Autonomous Region, southern China.

This new species is most similar, and probably related, to Aspidistra patentiloba Y. Wan \& X. H. Lu (Wan, 1989: 99) in its dilated, thickened stigma, which is longitudinally ridged abaxially, slightly concave adaxially, and triangular-lobed at the margin. However, the latter species, distributed in Liujiang County in central Guangxi (200 km northeast of Long'an), differs in having the stamens inserted at the middle of the perianth tube, positioned level with the stigma, the anthers ovate, and the stigma adaxially purple with four ridges at its center.

The floral structure of Aspidistra, especially the stigma, is the most important taxonomic character

Novon 13: 480-482. 2003. 


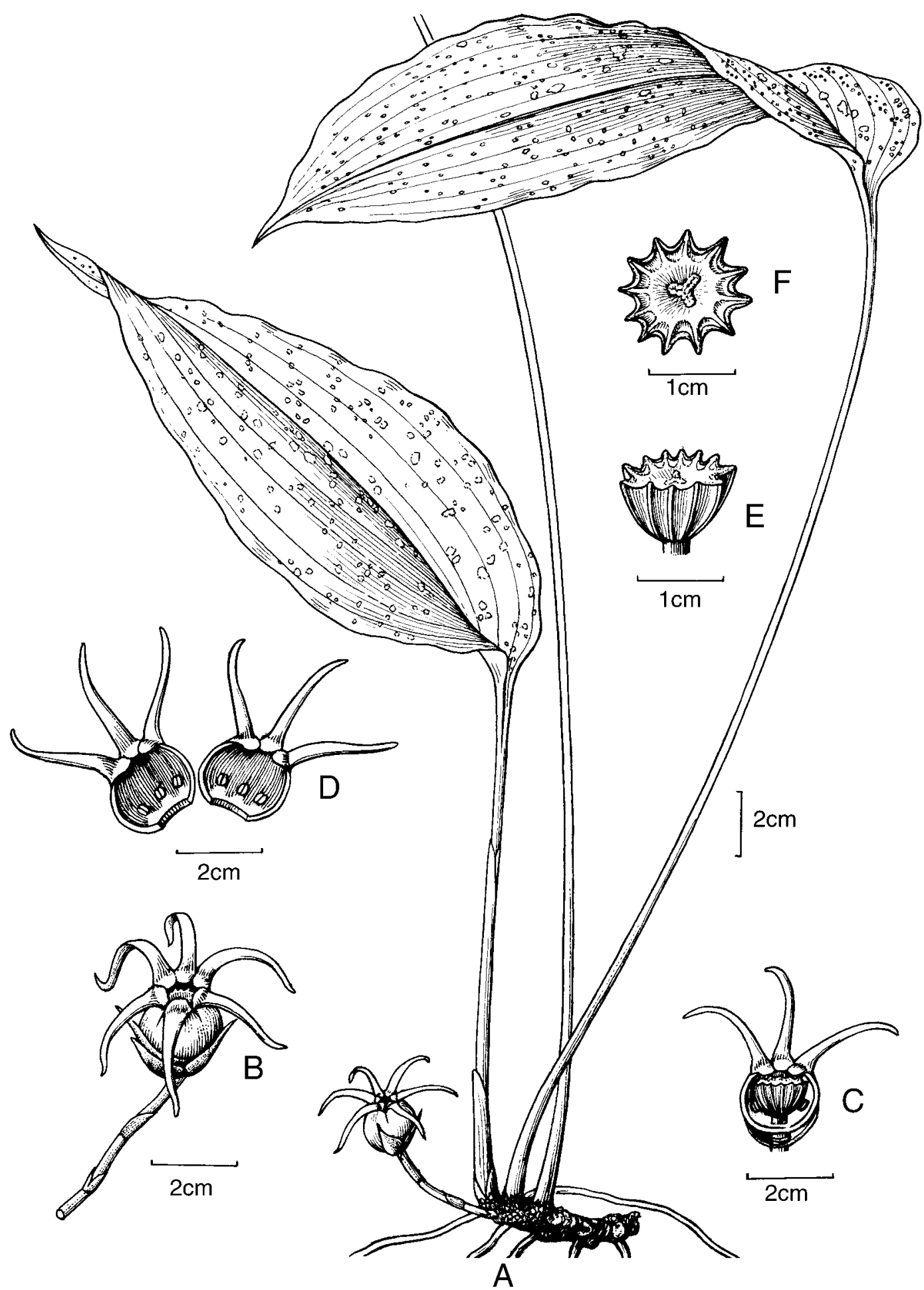

Figure 1. Aspidistra guangxiensis S. C. Tang \& Y. Liu. - A. Flowering plant. -B. Flower. —C. Flower with half of perianth removed showing stamens and pistil. —D. Perianth bisected. - E. Stigma lateral view. -F. Stigma apical view. Drawn from the holotype, Y. Liu 0001 (IBK), by He Shunqing. 
because of its great variation (Li et al., 2000). Both A. guangxiensis and A. patentiloba have been cultivated under the same environmental conditions at the Guilin Botanical Garden, where their floral differences hold true. Furthermore, one of us (Liu) collected material of A. guangxiensis from the botanical garden in 2003 and observed the floral structure to be the same as that of the type material collected in 2002. This demonstrates that the distinctness of A. guangxiensis from A. patentiloba is not an artifact of cultivation and that the diagnostic floral characters of the new species are constant.

Paratypes. CHINA. Guangxi: Guilin Botanical Garden, cultivated, 12 May 2002, Y. Liu 0002, originally collected from Guangxi, Long'an County, limestone mountains, $350 \mathrm{~m}$, date and collector not recorded (IBK).

Acknowledgments. We thank Deng Yunfei, South China Institute of Botany, Chinese Academy of Sciences (IBSC), and Nicholas Turland, Missouri Botanical Garden (MO), for their help in preparing the paper, and two anonymous reviewers for valuable comments. We also thank He Shunqing, Guangxi Institute of Botany, Guangxi Zhuangzu Autonomous Region, Chinese Academy of Sciences
(IBK), for drawing the illustration. This project is supported by the Special Fund for Taxonomy and Flora of the Chinese Academy of Sciences.

Literature Cited

Fang, D. \& L. Y. Yu. 2002. Three new species of Aspidistra Ker-Gawl. (Liliaceae) from Guangxi, China. Acta Phytotax. Sin. 40: 159-163.

He, S. Z. 2002. A new species of Aspidistra Ker-Gawl. (Liliaceae) from Guizhou, China. Acta Phytotax. Sin. 40: 377-379.

Lang, K. Y., G. Z. Li, Y. Liu, Y. G. Wei \& R. X. Wang. 1999. Taxonomic and phytogeographic studies on the genus Aspidistra Ker-Gawl. (Liliaceae) in China. Acta Phytotax. Sin. 37: 468-508.

Li, G. Z. \& S. C. Tang. 2002. New taxa of Aspidistra KerGawl. from Guangxi, China. Guihaia 22: 289-291.

, K. Y. Lang, R. X. Wang \& Y. G. Wei. 2000. On the trends of morphological differentiation and a new system of classification in Chinese Aspidistra Ker-Gwal. [sic] (Liliaceae). Guihaia 20: 201-217.

Liang, S. Y. \& M. N. Tamura. 2000. Aspidistra. Pp. 240 250 in: Z. Y. Wu \& P. H. Raven (editors), Flora of China, Vol. 24, Flagellariaceae through Marantaceae. Science Press, Beijing, and Missouri Botanical Garden Press, St. Louis.

Wan, Y. 1989. Three new species of the genus Aspidistra from Guangxi. Bull. Bot. Res., Harbin 9(2): 97-102. 